\title{
Evaluation of Dry Blood Spot (DBS) Stored at Different Temperature for Detection of HIV Antibodies by Using Different Rapid Tests
}

\author{
Mustafa EM Yassin ${ }^{1 *}$, Walid A Eldaif ${ }^{1}$ and Isam M Elkhider ${ }^{2}$ \\ ${ }^{1}$ Faculty of Medical Laboratory Sciences, Department of Medical Microbiology, Al Neelain University, Sudan \\ ${ }^{2}$ Faculty of Medicine, Department of Microbiology and Parasitology, University of Khartoum, Sudan
}

\section{Abstract}

Objective: To evaluate the uses of dry blood spot stored at $37^{\circ} \mathrm{C}, 45^{\circ} \mathrm{C}$, and $50^{\circ} \mathrm{C}$ for detection for HIV antibodies by using Rapid test.

Methods: 95 blood specimens were used in this study, 50 specimens were collected from HIV positive and 45 collected from HIV non reactive patient, Dry Blood Spots (DBS) were prepared by applying $50 \mu$ of whole blood on Whatman 3 filter paper (Whatman International ${ }^{\circledR} \mathrm{Ltd}$.), specimens of all DBS were stored at $37^{\circ} \mathrm{C}, 45^{\circ} \mathrm{C}$ and $50^{\circ} \mathrm{C}$.

All DBS were tested with two rapid tests $\left(A C O N^{\circledR}\right.$ One Step Test Device) and (ACCURATE ${ }^{\circledR}$ test device) and to evaluate the effect of storage temperature and time on sensitivity and specificity, DBS were tested after 2 weeks, 4 weeks and 8 weeks.

Results: After 2 weeks 48 out of 50 HIV-positive DBS were positive, and all 45 HIV-negative DBS were negative, at the different temperatures with both ICT test devices, with sensitivity of $(96 \%)$ and specificity of (100\%). After 4 weeks at $37^{\circ} \mathrm{C}$, no change was reported in sensitivity and specificity with the both rapid tests. There was decrease in sensitivity after 8 week storage, especially at higher temperatures $45^{\circ} \mathrm{C}$ and $50^{\circ} \mathrm{C}$.

Conclusion: When tested with rapid test, DBS stored at $37^{\circ} \mathrm{C}$ and $45^{\circ} \mathrm{C}$ showed good stability until 8 weeks, but when stored at $50^{\circ} \mathrm{C}$ it showed good stability until week 4 and it had less stability when stored for 8 weeks. The present study concluded that in area with high temperature such as Sudan DBS can be stored at room temperature and tested with rapid test within 4 weeks.

Keywords: HIV;Dry Blood Spot(DBS); Intraoperative Computerized Tomography (ICT); Sudan

\section{Introduction}

At the end of 2010, an estimated 34 million people (31.6 million-35.2 million) were living with HIV worldwide, up 17\% from 2001. Sub-Saharan Africa remains the region most heavily affected by HIV. In 2010, about $68 \%$ of all people living with HIV resided in subSaharan Africa, a region with only $12 \%$ of the global population. SubSaharan Africa also accounted for 70\% of new HIV infections in 2010 [1].

Dried blood specimens are clinical specimens collected by careful applying of a few drops of blood, freshly drawn by finger stick with a lancet from adults, or by heel stick from infants, onto specially manufactured absorbent specimen collection (filter) paper [2], for example Schleicher and Schuell (S and S) 903, S and S 2992, and Whatman grade 1 or $3[2,3]$. The blood is allowed to thoroughly saturate the filter paper and is air dried for a minimum of three hours [2]. It is a well- accepted means of collection, transport and storage of blood samples for various epidemiologic, serologic and molecular assays for Human Immunodeficiency Virus (HIV) studies [4]. Particularly important for mother to infant transmission studies of affected individual living in remote areas, and for large-scale, population based screening programs [4].

Testing of blood dried on filter paper introduced by Robert Guthrie (hence it also called Guthrie spot) in 1960s to collect blood by heel stick, for measurement of phenylalanine in newborns to detect Phenylketonuria (PKU) [5].

Testing neonatal DBS for maternal HIV antibodies, using Enzyme Immunoassay (EIA) and immunoblot (IB) was first described in 1987 [6]. In 1994 testing of DBS for the presence of HIV type 1 proviral DNA by PCR was first described [7].

\section{Materials and Methods}

Confirmed HIV positive specimens (ELISA and Immunoplot positive) and HIV test negative specimens (ELISA and Immunoplot negative) were enrolled into this study. Three $\mathrm{ml}$ of venous blood was collected into EDTA container, and DBS was prepared on Whatman 3 (Whatman International ${ }^{\circledR}$ Ltd.). Filter paper was cut into strips, each strip used for preparation of 4 DBS. Three DBS strips were prepared from each sample.

One end of each strip was used for sample identification, including labelling number, date of collection, and temperature of storage. DBS was prepared by applying $50 \mu \mathrm{l}$ of EDTA anticoagulated whole blood on filter paper, then it was positioned horizontally at rack, allowed to dry at room temperature for about 3 hours, and then each strip was enclosed separately in a plastic bag. From each sample three DBS strips were made and one was stored at $37^{\circ} \mathrm{C}$, the second one was stored at $45^{\circ} \mathrm{C}$ and the $3 \mathrm{rd}$ one was stored at $50^{\circ} \mathrm{C}$. Storage temperatures were selected to mimic ambient temperatures in Sudan that could reach more than $45^{\circ} \mathrm{C}$ in the summer season.

*Corresponding author: Mustafa EM Yassin, Faculty of Medical Laboratory Sciences, Department of Medical Microbiology, Al Neelain University, Sudan, Tel: +249-912617978; E-mail: mustafaeltigani@gmail.com

Received December 28, 2012; Accepted January 25, 2013; Published February 03, 2013

Citation: Yassin MEM, Eldaif WA, Elkhider IM (2013) Evaluation of Dry Blood Spot (DBS) Stored at Different Temperature for Detection of HIV Antibodies by Using Different Rapid Tests. Surgery S12: 002. doi:10.4172/2161-1076.S12-002

Copyright: (C) 2013 Yassin MEM, et al. This is an open-access article distributed under the terms of the Creative Commons Attribution License, which permits unrestricted use, distribution, and reproduction in any medium, provided the original author and source are credited. 
Citation: Yassin MEM, Eldaif WA, Elkhider IM (2013) Evaluation of Dry Blood Spot (DBS) Stored at Different Temperature for Detection of HIV Antibodies by Using Different Rapid Tests. Surgery S12: 002. doi:10.4172/2161-1076.S12-002

Page 2 of 3

\section{Elution of DBS for testing}

DBS was punched with manual 1-hole punch (Staples ${ }^{\circledR}$ Brands Group) for $1 / 4$ inch $(6.35 \mathrm{~mm})$ punch, in an area that is fully saturated with blood. Elution was prepared with $200 \mu \mathrm{l}$ phosphate buffered saline with $0.05 \%$ Tween 20 (PBST).

Elution with $200 \mu \mathrm{PBST}$ was selected on basis of preliminary results that indicated superiority to other volume tested $(100 \mu \mathrm{l}$ and $300 \mu \mathrm{l})$.

Elutions were prepared after 2 weeks, 4 weeks and 8 weeks for testing with ICT.

Two rapid tests were used: ACON HIV 1/2 (Human Immunodeficiency Virus Ultra Rapid Test Device. ACON Laboratories and ACCURATE HIV 1/2 (Human Immunodeficiency Virus Ultra Rapid Test Device), these tests are used widely in Sudan as screening test at the low resources regions.

\section{Test method}

Test device, specimen and buffer were allowed to equilibrate to room temperature prior testing. The tests were carried out according to manufactures direction. Positive result was indicated by appearance of two red lines within 10 minutes.

\section{Results}

Replicates of $50 \mathrm{HIV}$ positive DBS stored at $37^{\circ} \mathrm{C}, 45^{\circ} \mathrm{C}$, and $50^{\circ} \mathrm{C}$ were tested with rapid test (ACCURATE ${ }^{\circledR}$ test device) after 2 weeks, 4 weeks and 8 weeks intervals (Table 1). 48 DBS samples were still positive at different temperature until 4 weeks, after 8 weeks storage at $37^{\circ} \mathrm{C}$ and $45^{\circ} \mathrm{C}$ two samples were changed from positive to negative, at $50^{\circ} \mathrm{C}$ six samples were changed to negative. On the other hand all HIV negative DBS were negative at the different temperature and storage time. As shown in ( Table 2), $50 \mathrm{HIV}$ positive DBS stored at $37^{\circ} \mathrm{C}, 45^{\circ} \mathrm{C}$, and $50^{\circ} \mathrm{C}$ were tested with rapid test $\left(A C O N^{\mathbb{B}}\right.$ One Step Test Device), after 2 weeks, 4 weeks and 8 weeks intervals. 48 DBS samples were positive after two weeks at the different temperature. After four weeks at $37^{\circ} \mathrm{C} 48$ sample were still positive, where as 47 samples were found positive at a temperature of $45^{\circ} \mathrm{C}$ and 46 samples positive at $50^{\circ} \mathrm{C}$. A Few discrepancies were observed after 8 weeks storing, $46 \mathrm{DBS}$ samples were positive at temperature of $37^{\circ} \mathrm{C}, 45$ samples were positive at $45^{\circ} \mathrm{C}$, while 42 samples were found positive at $50^{\circ} \mathrm{C}$.

As illustrated in (Figure 1) out of $50 \mathrm{HIV}$ positive samples, after 4 weeks storage at $37^{\circ} \mathrm{C}$ the two rapid test gave same result (48 positive DBS), while at $45^{\circ} \mathrm{C} 48$ DBS samples were positive with ACCURATE compared with 47 DBS positive samples with ACON, whereas 46 DBS samples were positive with $A C O N$ compared with 48 DBS positive with ACCURATE at a temperature of $50^{\circ} \mathrm{C}$.

In figure 2 after 8 weeks storing at $37^{\circ} \mathrm{C}, 45^{\circ} \mathrm{C} \& 50^{\circ} \mathrm{C}, 46 \mathrm{DBS}$ stored at $37^{\circ} \mathrm{C}$ were positive with both rapid tests, at $45^{\circ} \mathrm{C} 45 \mathrm{DBS}$ samples were still positive for HIV with ACON compared with $46 \mathrm{DBS}$ samples with ACCURATE, whereas only $42 \mathrm{DBS}$ stored at $50^{\circ} \mathrm{C}$ were positive with both tests.

As indicated in (Table 3 ) the sensitivity \& specificity of both rapid simple tests were $84 \%-96 \%$ and $100 \%$ respectively.

\section{Discussion}

In this study we used Dry Blood Spot (DBS) stored for various times at different temperatures for detection of HIV-1/2 antibodies with two rapid test $\left(A C O N^{\circledR}\right.$ One Step Test Device) and (ACCURATE ${ }^{\circledR}$ test device) [8].

\begin{tabular}{|l|l|l|l|}
\hline \multirow{2}{*}{ Storing duration } & \multirow{2}{*}{ Temperature } & \multicolumn{2}{|l|}{ ACCURATE $^{\circledR}$ test device } \\
\cline { 2 - 4 } & Positive n (\%) & Negative n (\%) \\
\hline \multirow{2}{*}{ 2 weeks } & $37^{\circ} \mathrm{C}$ & $48(96)$ & $2(4)$ \\
\hline \multirow{4}{*}{ 4 weeks } & $45^{\circ} \mathrm{C}$ & $48(96)$ & $2(4)$ \\
\hline $50^{\circ} \mathrm{C}$ & $48(96)$ & $2(4)$ \\
\hline \multirow{5}{*}{8 weeks } & $37^{\circ} \mathrm{C}$ & $48(96)$ & $2(4)$ \\
\hline & $45^{\circ} \mathrm{C}$ & $48(96)$ & $2(4)$ \\
\hline $50^{\circ} \mathrm{C}$ & $48(96)$ & $2(4)$ \\
\hline & $37^{\circ} \mathrm{C}$ & $46(92)$ & $4(8)$ \\
\hline & $45^{\circ} \mathrm{C}$ & $46(92)$ & $4(8)$ \\
\hline $50^{\circ} \mathrm{C}$ & $42(84)$ & $8(16)$ \\
\hline
\end{tabular}

Table 1: The effect of temperature and storage time on testing of $50 \mathrm{HIV}$ positive DBS samples with ACCURATE ${ }^{\circledR}$ rapid test.

\begin{tabular}{|l|l|l|l|}
\hline \multirow{2}{*}{ Storing duration } & \multirow{2}{*}{ Temperature } & \multicolumn{3}{|l|}{ ACON ${ }^{\circledR}$ One Step Test Device } \\
\cline { 3 - 4 } & & Positive n (\%) & Negative n (\%) \\
\hline \multirow{4}{*}{ 2 weeks } & $37^{\circ} \mathrm{C}$ & $48(96)$ & $2(4)$ \\
\hline \multirow{4}{*}{ 4 weeks } & $45^{\circ} \mathrm{C}$ & $48(96)$ & $2(4)$ \\
\cline { 2 - 4 } & $50^{\circ} \mathrm{C}$ & $48(96)$ & $2(4)$ \\
\hline \multirow{5}{*}{8 weeks } & $37^{\circ} \mathrm{C}$ & $48(96)$ & $2(4)$ \\
\hline & $45^{\circ} \mathrm{C}$ & $47(94)$ & $3(6)$ \\
\hline $50^{\circ} \mathrm{C}$ & $46(92)$ & $4(8)$ \\
\hline & $37^{\circ} \mathrm{C}$ & $46(92)$ & $4(8)$ \\
\cline { 2 - 4 } & $45^{\circ} \mathrm{C}$ & $45(90)$ & $5(10)$ \\
\hline $50^{\circ} \mathrm{C}$ & $42(84)$ & $8(16)$ \\
\hline
\end{tabular}

Table 2: The effect of temperature and storage time on testing of 50 HIV positive DBS samples with $A C O N^{\circledR}$ rapid test.

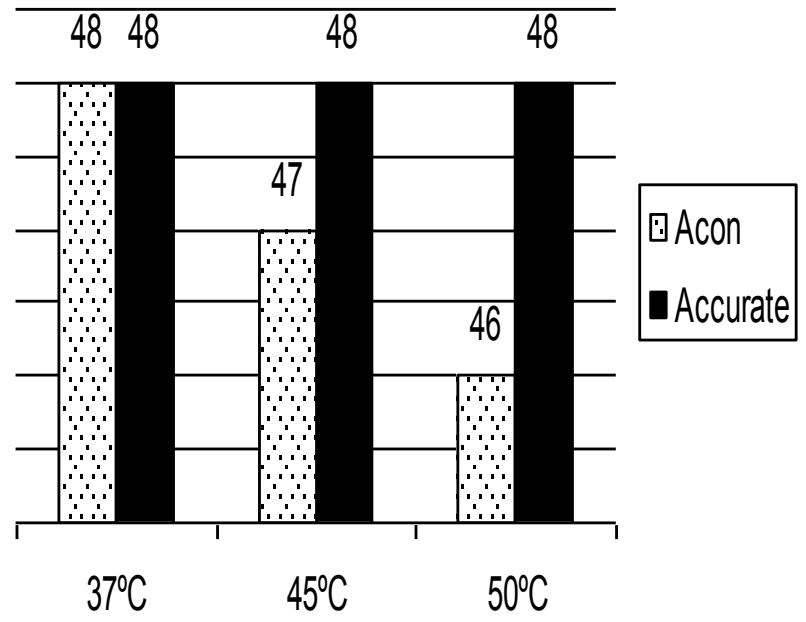

Figure 1: Result of DBS stored for 4 weeks at $37^{\circ} \mathrm{C}, 45^{\circ} \mathrm{C}$, and $50^{\circ} \mathrm{C}$ tested with $\left(A C O N^{\circledR}\right.$ One Step Test Device), and (ACCURATE ${ }^{\circledR}$ test).

Testing of DBS stored at $37^{\circ} \mathrm{C}, 45^{\circ} \mathrm{C}$, and $50^{\circ} \mathrm{C}$ for two weeks, with rapid tests $\left(A C O N^{\circledR}\right.$ One Step Test Device and ACCURATE ${ }^{\circledR}$ test device), showed sensitivity of $96 \%$ and specificity of $100 \%$ for both. This result is quite similar to study done by Thakar et al. [9] in who reported the sensitivity of (Immunocomb $\Pi$ HIV 1 and 2 bispot test kit) for detection of HIV-1/2 antibodies was $100 \%$, and that of OuweMissi-Oukem-Boyer et al. [10] in Niger [10] who used two rapid tests (Determine HIV 1/2 and Immunocomb II HIV 1 and 2 Bispot) to compare the dried blood spots and serum. The authors' reported similar results for the two tests used. This study also indicated some consent with the study done by Mei et al. in 2004 [11], who investigated the use of DBS with three rapid test (OraQuick, Determine and Uni- 
Citation: Yassin MEM, Eldaif WA, Elkhider IM (2013) Evaluation of Dry Blood Spot (DBS) Stored at Different Temperature for Detection of HIV Antibodies by Using Different Rapid Tests. Surgery S12: 002. doi:10.4172/2161-1076.S12-002

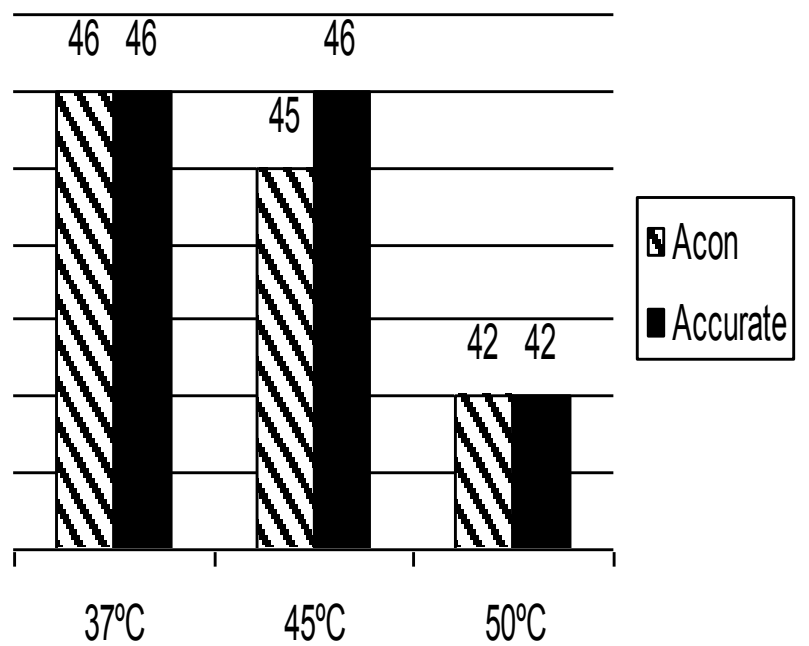

Figure 2: Result of DBS tested after 8 weeks storage at $37^{\circ} \mathrm{C}, 45^{\circ} \mathrm{C}$, and $50^{\circ} \mathrm{C}$, with $\left(A C O N{ }^{\circledR}\right.$ One Step Test Device), and (ACCURATE ${ }^{\circledR}$ test device).

\begin{tabular}{|c|c|c|c|c|c|}
\hline \multirow{3}{*}{$\begin{array}{l}\text { Storing } \\
\text { duration }\end{array}$} & \multirow{3}{*}{ Temperature } & \multicolumn{4}{|l|}{ Rapid Test } \\
\hline & & \multicolumn{2}{|c|}{$\begin{array}{l}\text { ACCURATE }{ }^{\circledR} \text { test } \\
\text { device }\end{array}$} & \multicolumn{2}{|c|}{$\begin{array}{l}\text { ACON }{ }^{\circledR} \text { One Step Test } \\
\text { Device }\end{array}$} \\
\hline & & $\begin{array}{l}\text { Sensitivity } \\
\%\end{array}$ & $\begin{array}{l}\text { Specificity } \\
\%\end{array}$ & Sensitivity \% & Specificity \% \\
\hline \multirow{3}{*}{2 weeks } & $37^{\circ} \mathrm{C}$ & 96 & 100 & 96 & 100 \\
\hline & $45^{\circ} \mathrm{C}$ & 96 & 100 & 96 & 100 \\
\hline & $50^{\circ} \mathrm{C}$ & 96 & 100 & 96 & 100 \\
\hline \multirow{3}{*}{4 weeks } & $37^{\circ} \mathrm{C}$ & 96 & 100 & 96 & 100 \\
\hline & $45^{\circ} \mathrm{C}$ & 96 & 100 & 94 & 100 \\
\hline & $50^{\circ} \mathrm{C}$ & 96 & 100 & 92 & 100 \\
\hline \multirow{3}{*}{8 weeks } & $37^{\circ} \mathrm{C}$ & 92 & 100 & 92 & 100 \\
\hline & $45^{\circ} \mathrm{C}$ & 92 & 100 & 90 & 100 \\
\hline & $50^{\circ} \mathrm{C}$ & 84 & 100 & 84 & 100 \\
\hline
\end{tabular}

Table 3: Sensitivity and specificity of DBS stored at $37^{\circ} \mathrm{C}, 45^{\circ} \mathrm{C}$, and $50^{\circ} \mathrm{C}$ tested with the two rapid tests after storage for two, four and eight week.

Gold) and reported that the specificity were $100 \%, 80 \%-89 \%$ and $73 \%$ $80 \%$ respectively.

All HIV negative DBS were negative at all temperature and time (specificity $100 \%)$.

In the current study, anti-HIV antibodies show good stability on
DBS when stored at $37^{\circ} \mathrm{C}$ and $45^{\circ} \mathrm{C}$ for up to eight weeks. DBS stored at $50^{\circ} \mathrm{C}$ were stable up to four weeks, but when stored for eight weeks, sensitivity was progressively declined. Specificity was not affected with temperature or time of storage.

Rapid test can be used successfully with DBS. In country with high temperature such as Sudan, DBS can be stored at ambient temperature without need for refrigerators up to two weeks.

\section{Acknowledgements}

Special thanks to all staff of Medical Microbiology department, Faculty of Medical Laboratory Sciences, Al-Neelain University, for their support and continues assistance through the whole process of this research. We would like to express our deep gratitude to Omar Nemairy center, Umdurman Teaching Hospital.

\section{References}

1. UN AIDS (2011) World AIDS Day Report.

2. Knudsen RC, Slazyk WE, Richmond JY, Hannon WH (1993) Guidelines from the Centers for Disease Control and Prevention for the shipment of dried blood spot specimens. Safety and health monograph: guidelines for the shipment of dried blood spot specimens. Atlanta: Centers for Disease Control and Prevention, 1-4.

3. Williamson $\mathrm{J}$ (1997) The utility of bloodspot technologies in low income technologies. (In: Improved care of the diseases childhood, London: Centre for International Child Health)

4. Luo W, Yang H, Rathbun K, Pau CP, Ou CY (2005) Detection of human immunodeficiency virus type 1 DNA in dried blood spots by a duplex real-time PCR assay. J Clin Microbiol 43: 1851-1857.

5. Guthrie R, Susi A (1963) A simple phenylalanine method for detecting phenylketonuria in large populations of newborn infants. Pediatrics 32: 338 343.

6. Pappaioanou M, Kashamuka M, Behets F, Mbala S, Biyela K, et al. (1993) Accurate detection of maternal antibodies to HIV in newborn whole blood dried on filter paper. AIDS 7: 483-488.

7. Cassol S, Butcher A, Kinard S, Spadoro J, Sy T, et al. (1994) Rapid screening for early detection of mother-to-child transmission of human immunodeficiency virus type 1. J Clin Microbiol 32: 2641-2645

8. Sarge-Njie R, Schim Van Der Loeff M, Ceesay S, Cubitt D, Sabally S, et al (2006) Evaluation of the dried blood spot filter paper technology and five testing strategies of HIV-1 and HIV-2 infections in West Africa. Scand J Infect Dis 38 1050-1056.

9. Thakar MR, Ghate MV, Paranjape RS (2000) Collection of blood on filter paper stability and validation study for HIV serology. Indian Journal of Community Medicine 4: 184-3.

10. Ouwe-Missi-Oukem-Boyer ON, Hamidou AA, Sidikou F, Garba A, LouboutinCroc JP (2005) The use of dried blood spots for HIV-antibody testing in Sahel. Bull Soc Pathol Exot 98: 343-346.

11. Mei JV, Tanuri A, Rayfield M, Hannon WH (2004) Use of dried blood spots with HIV rapid tests. International Conference of AIDS Bangkok, Thailand 11-16. 